\begin{tabular}{ll}
\hline 論 & 説 \\
\hline
\end{tabular}

\title{
先天性外耳道閉鎖症の臨床
}

一 外耳道形成と聴力改善 -

増田 游・渡邊 周一・服部 謙志

\section{Clinical Aspects of Congenital Aural Atresia}

- Canaloplasty and Tympanoplasty -

\author{
Yu Masuda, Shuichi Watanabe and Kenshi Hattori \\ (Okayama University)
}

The Authors describe 8 years of experience with the surgical management of 31 ears with complete and 6 ears with incomplete congenital aural atresia.

Canaloplasty was performed in 18 ears and tympanoplasty in 19 ears. In this series there were 28 males and 6 females, aged 5 to 44 years at the time of surgery.

Surgical attempts to improve hearing were tried in all 37 ears but failed in 18 because of inability to reach the tympanic cavity by interruption of surgery due to profuse bleeding, leakage of liquor, damage to the capsule of the temporomandibular joint, etc.

The success rate was $27.8 \%$ with canaloplasty and $84.2 \%$ with tympanoplasty, based on postoperative average hearing levels of $35 \mathrm{~dB}$ or less for $0.5,1$ and $2 \mathrm{kHz}$. The final success rate with tympanoplasty was $63.2 \%$ based on the average hearing levels at the last examination. The average follow-up period was 2.5 years for tympanoplasty cases.

The results led to the following conclusions:

1. Stenosis of the reconstructed external auditory canal was prevented by creation of a canal with at least 1.5 times the normal diameter.

2. The presence of a mobile stapedial footplate results in satisfactory hearing improvement in most cases of middle ear anomaly, especially when tympanoplasty is performed.

3. Lateralization of the reconstructed tympanic membrane is the primary cause of hearing loss following initial improvement.

Key words: congenital aural atresia, hearing improvement, canaloplasty, tympanoplasty

はじめに

先天性外耳道閉鎖症 (先天鎖耳) は, 臨床統計

上伝音性難聴を呈する聴器奇形のうち, その過 半数を占める極めて治療困難な疾患であること
は, 伝音難聴への聴力改善手術が進んでいる現 在に掞いても，変わることのない事実である。

私どもは，すでに30年以上にわたって，伝音 系奇形耳への聴力改善手術を，かなり積極的に 
行ってさたが，その成果となると，先天鎖耳に ついては，手放しで喜べないものがある，その 第一は，たと党初回手術によって臨床上有用な 聴力改善を得ても, 形成された外耳道が再び狭 窄や閉鎖をきたし，場合によってはせっかく上 皮化した形成外耳道内腔上皮か 2 次的な真珠腫 発症の原因となり得ること，またそのために再 び伝音性難聴をきたすむとである。また，曲り なりにも奇形耳小骨連鎖を利用して改善聴力を 得ても，形成鼓膜の洀痕性退縮などで耳小骨連 鎖との接触がなくなるために，術後 1 年を待た ずして聴力低下が起こる例もあることである。

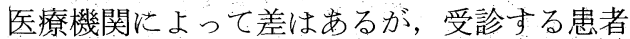
の奇形病態によって手術の難易度も決まるので, 当然それによっても手術成績が左右される点も あり，症例によっては，側頭骨の削開を進めて も，どらしても鼓室に到達し得ない例もあるの で，本来先天鎖耳にあっては，前述の再狭窄の 点も考光ると，外耳道形成術の成否が，本症手 術の成否の要因の大部分であるともいえよう。

私どもは，これら諸点について改めて検討す ベく, 先天鎖耳の聴力改善と改善聴力の維持に 関して，最近例を集計する機会を得たので，こ れを中心に述べてみる。

\section{観察対象と結果}

対象は, 昭和 57 年 1 月から平成元年12月まで の 8 年間に, 岡山大学耳鼻咽喉科学教室で聴力 改善を目的に手術を行った，先天鎖耳を主とす る先天性外耳道異常症例34例 37 耳である。いず れも初回手術を受けた症例に限って検討した。

表 1 対象症例 (昭和57年～平成元年)

\begin{tabular}{cc}
\hline \hline 外耳道完全閉鎖症 & \\
両側性 & 3 例 5 耳 \\
片側性 & 26 例 $26 耳$ \\
外耳道不完全閉鎖症 (狭窄または狭小) \\
両側性 & 1 例 2 耳 \\
片側性 & 4 例 4 耳 \\
\hline 計 & 34 例 37 耳(男28例, 女 6 例)
\end{tabular}

小耳症合併 33 耳 $(89.2 \%)$
対象症例の内訳は，外耳道完全閉鎖の 29 例 31 耳之，不完全閉鎖(狭小あるいは狭窄)の 5 例 6 耳である(表 1 )。男28例，女 6 例で，初回手術 時年齢分布は 5 歳から44歳にわたり，10歳以下 のもの12例で, 平均13.7歳であった(表 2 ).

適応術式は，まず外耳道形成術，そして，た とえ異常な耳小骨連鎖であっても，卵円空を経 ての伝音効果が期待できる例では，鼓室形成術 を第一選択として行った。

初回手術時の入院期間中での聴力改善状態を もってその聴力成績をみると，表 3 のごとくで, 全37耳中，外耳道形成術にとどまったものは18 耳, 鼓室に到達し耳小骨連鎖を確認して鼓室形 成術を行い得たもの 19 耳であり，0.5，1，2 $\mathrm{kHz}$ での 3 分法による平均聴力レベルで術後 11 $\mathrm{dB}$ 以上改善したか，平均聴力レベルが $35 \mathrm{~dB}$ 以内になったものを改善例とすると，外耳道形 成術での聴力改善率は $27.8 \%$, 鼓室形成術での それは $84.2 \%$ であった。

外耳道形成術にとどまった症例について，側 頭骨の削開で鼓室に到達し得なかったものと， 到達したが，聴力改善操作をし得なかったもの

表 2 年齢分布 (初回手術時)

\begin{tabular}{c|c}
\hline \hline $5 \sim 10$ & 12 \\
$11 \sim 15$ & 10 \\
$16 \sim 20$ & 7 \\
21 以上 & 5 \\
\hline $5 \sim 44$ 歳 & 34 例
\end{tabular}

平均 13.7 歳

表 3 初回手術成績

\begin{tabular}{c|c|c|c}
\hline \hline \multicolumn{2}{l|}{} & 成功耳数 & 成功率 $(\%)$ \\
\hline $\begin{array}{c}\text { 外耳道形成術 } \\
\text { 鼓室形成術 }\end{array}$ & 18 耳 & 5 & 27.8 \\
& 19 耳 & 16 & 84.2 \\
& 37 耳 & 21 & 56.8
\end{tabular}


とついてみると，18耳中前者が12耳，後者が 6 耳であった。专た，後者の 6 耳中初回手術時聴 力改善を得たものは 3 耳であり，到達し得た中 耳腔が極めて小さく，耳小骨の存在も不明確な ままでも，いわゆる Meurman ${ }^{1)}$ の法に準じて 耳小骨に移植弁を接することができれば，結果 的には聴力改善を得ている. また中耳腔に達し 得なからた 12 耳は，いずれも CT上中耳腔の大 きさ・形態の異常はあるものの，その存在と奇 形性耳小骨らしいものの存在は認められて扣り, one tunnel 法による削開中の disorientation， 出血や脳脊髄液の漏出, 顎関節囊の損傷などに よる施術の中止をみている。その中には，再手 術にようて鼓室に到達しながら，そこで遭遇し た，アブミ骨の欠除, 両内耳空の欠除など, 高
度奇形のために聴力改善手術を断念した例もあ った。杰た，外耳道形成術例中術後の外耳道狭 窄で拡大術を行ったものが 4 耳あり，これにつ いては，考察の項で述べる。

初回手術で中耳腔への足がかりを得，結果的 に鼓室形成術による聴力改善手術を行った19耳 について，その術式と入院時聴力改善成績，そ の後の経過として後日再手術施行の有無や聴力 follow upの結果など，また現在までの観察期 間も含めて一括表示したのが表 4 である。術式 別には，鼓室形成術 I 型 1 耳， II 型10耳，亚型 8 耳で，それぞれの術後聴力改善率は，100 $\%(1 / 1), 80 \%(8 / 10) ， 87.5 \%(7 / 8)$ であった。

初回手術後再手術を受けたものは 6 耳で，丂 ち 1 耳は, 術後の外耳道狭小化のため, 初回手

表 4 鼓室形成術例概観

\begin{tabular}{|c|c|c|c|c|c|c|c|c|c|c|}
\hline \multirow{2}{*}{$\begin{array}{l}\text { 症例 } \\
\text { No. }\end{array}$} & \multirow{2}{*}{ 氏 名 } & \multirow{2}{*}{ 年齢·性 } & \multirow{2}{*}{ 病 名 } & \multirow{2}{*}{ 術 式 } & \multicolumn{2}{|c|}{ 聴 力 } & \multicolumn{2}{|c|}{ 再:手 術 } & \multirow{2}{*}{ 観察期間 } & \multirow{2}{*}{ 最終聴力 } \\
\hline & & & & & 術 前 & 術 後 & 時 期 & 術 式 & & \\
\hline 2 & & $11 \mathrm{M}$ & 右鎖 & III変 & $65(8)$ & 37 & $1 y$ & III変 & $6 y$ & $42(8)$ \\
\hline 3 & & $5 \mathrm{M}$ & 両鎖, 右 & III変 & $60(5)$ & 53 & $1 \mathrm{y}$ & III変 & $5 \mathrm{y} 4 \mathrm{~m}$ & $61(5)$ \\
\hline 5 & & $17 \mathrm{~F}$ & 左鎖 & II & $65(10)$ & 42 & $1 \mathrm{y}$ & III変 & $1 \mathrm{y} 2 \mathrm{~m}$ & $37(12)$ \\
\hline 6 & & $11 \mathrm{M}$ & 右鎖 & II & $67(10)$ & 27 & $1 \mathrm{y}$ & II変 & $3 y$ & $66(5)$ \\
\hline 7 & & $12 \mathrm{~F}$ & 右狭 & II & $55(8)$ & 35 & & & $2 \mathrm{y} 9 \mathrm{~m}$ & 53 \\
\hline 10 & & $7 \mathrm{M}$ & 右鎖 & II & $67(12)$ & 37 & $2 y$ & III変 & $4 y$ & $36 \quad(3)$ \\
\hline 3 & & $7 \mathrm{M}$ & 両鎖, 左 & III変 & $42(7)$ & 30 & & & $4 y$ & $30(3)$ \\
\hline 11 & & $8 \mathrm{M}$ & 右鎖 & III変 & $67(12)$ & 47 & $3 \mathrm{M}$ & 拡大 & $2 \mathrm{y} 8 \mathrm{~m}$ & 66 \\
\hline 14 & & $23 \mathrm{~F}$ & 右鎖 & II & $65(13)$ & 60 & & & $3 \mathrm{~m}$ & 60 \\
\hline 18 & & $6 \mathrm{M}$ & 右鎖 & II & $42(5)$ & 42 & & & $2 \mathrm{y} 9 \mathrm{~m}$ & $45(-2)$ \\
\hline 25 & & $9 \mathrm{M}$ & 右鎖 & II & $63(10)$ & 33 & & & $7 \mathrm{~m}$ & $47(-5)$ \\
\hline 27 & & $16 \mathrm{~F}$ & 両鎖, 右 & I & $33(0)$ & 5 & & & $1 \mathrm{~m}$ & 5 \\
\hline 28 & & $12 \mathrm{~F}$ & 左鎖 & 而変 & $47(3)$ & 23 & & & $5 \mathrm{y} 5 \mathrm{~m}$ & $27(5)$ \\
\hline 29 & & $18 \mathrm{M}$ & 左鎖 & II & $62(12)$ & 23 & & & $2 \mathrm{~m}$ & $23(12)$ \\
\hline 30 & & $20 \mathrm{M}$ & 左鎖 & II & $52(22)$ & 33 & & & $2 \mathrm{y} 5 \mathrm{~m}$ & 47 (18) \\
\hline 31 & & $13 \mathrm{M}$ & 左鎖 & III変 & $53(3)$ & 23 & & & $3 y 3 \mathrm{~m}$ & $30(5)$ \\
\hline 32 & & $13 \mathrm{M}$ & 右鎖 & II & $60(10)$ & 40 & & & $3 \mathrm{y} 7 \mathrm{~m}$ & $40(8)$ \\
\hline 33 & & $18 \mathrm{M}$ & 左鎖 & 正変 & $73(20)$ & 53 & & & $1 \mathrm{~m} 1 \mathrm{w}$ & 5,3 \\
\hline 34 & & $16 \mathrm{M}$ & 右狭 & III & $60(10)$ & 33 & & & $1 \mathrm{y}$ & $30(5)$ \\
\hline
\end{tabular}

衈力は 4 分法による $\mathrm{dB}$ 值

（）内は骨導値を示す
鎖 : 鎖耳 (先天性外耳道閉鎖症)

狭：狭窄むたは狭小

$\mathrm{M}$ : male $\mathrm{F}$ : female

$\mathrm{y}$ : year $\mathrm{m}$ : month $\mathrm{w}$ : week 
術後 3 力月で外耳道再形成(拡大術)を行った。 残る 5 耳では，いずれも術後 1 年から 2 年の間 に, 術後の改善聴力が低下したため再手術を受 けている。

鼓室形成術症例で, 観察期間内の最終聴力レ ベルをみると, 術後観察期間は最短 1 カ月から 最長 6 年末で, 平均術後 2 年 6 力月であり, 最 終聴力レベルで術後成績をみると，19耳中12耳 で改善聴力を維持して掊り，その改善率は63.2 \%となる。

考 察
すでに本稿はじめに述べたように，先天鎖耳 での聴力改善を成功させる基本的条件に 3 つあ る. 一つは中耳腔と一体化した外耳道形成術を 行うこと，そして中耳伝音系を形成してこれを 形成外耳道に直結し, 聴力改善を得ること, 最 後に，その得られた改善聴力を永続させること である.これらを中心に，今回私どもが集計し た37耳からの結果を基に述べてみたい。

1 ) 外耳道形成について

このシリーズの結果からも明らかなように， 外耳道異常例での骨削開で鼓室を開放すること は，それ程容易なことではない、特に，私ども は, one tunnel 法2)を行って招り, 当然 disorientationの頻度も高くなる。骨削開始部位は，顎 関節に接するその後方である. 関節窩のすぐ後 方には，耳介奇形の軽度な例では骨粗面をみ， その前方には外耳道上棘様の小突起がある。耳 介奇形高度な例でも，この部に窪みがみとめら れることもあり，一つのランドマークともなる. 削開は，ここから始めて，上鼓室，鼓室へと到 ってこれを開放する(図 1，2）。安全性の点か らは，乳突洞を出し，中頭蓋窩天蓋の脳硬膜も 確認して，これを指標に鼓室に入る力法が確実 である。しかし，指南上の困難はあるが，形成 外耳道のゆが久が少なく, 過大な創腔のための 術後管理上の問題もないので, 私どもは幼小児 でも内径 $1 \mathrm{~cm}$ 以上を目安にして, 形成外耳道 を one tunnel 法で作っている.

経験的にいえば，先天鎖耳で削開中鼓室の指
南に苦しむ時は, 関節窩の上を跨ぐように前下 方に向うと鼓室に到達し易い印象もあり，その ため術中顎関節窝を覆う骨膜が露出することは 少なくない。しかし，関節垔を損傷しないかぎ り，関節の機能的障害はない3).

中耳腔と一体化した外耳道形成を成功させる

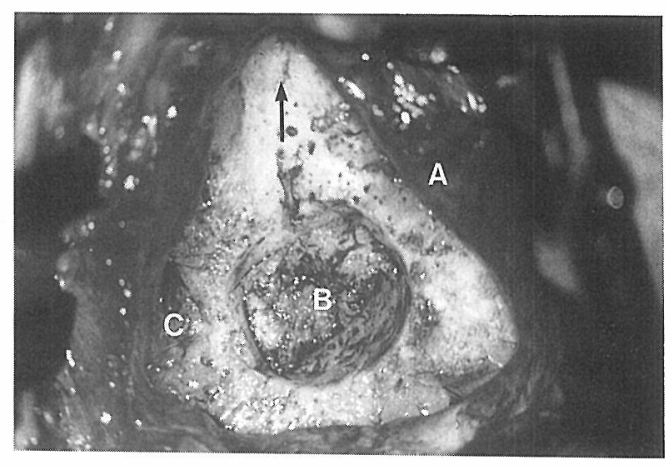

図 1 骨部外耳道形成時の削開部位 (左耳) A：上万，側頭線まで橎転された骨膜弁 $\mathrm{B}$ : 削開中の外耳道 (one tunnel 法) C : 䪽関節窩

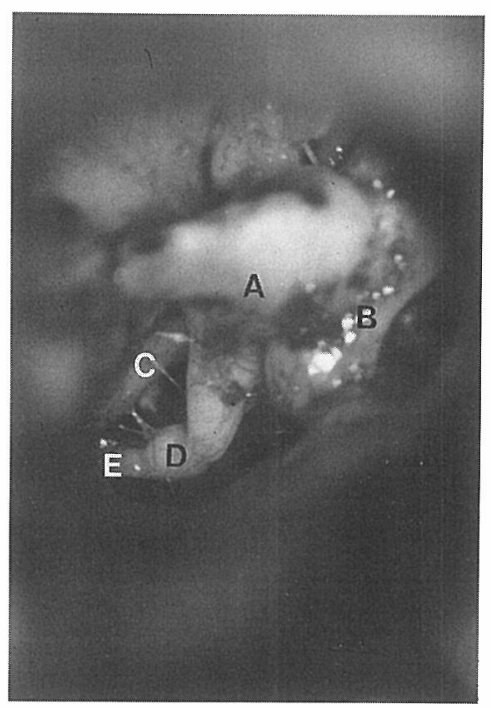

図 2 開放された上鼓室(右耳)

A：キヌタ骨体部

B：柄を欠くッチ骨

C : 顔面神経管水平部

D：キヌタ骨豆状突起

E : アブミ骨筋腱 
ことは，そのあとの聴力改善といら目的に直結 するものであり，奇形耳介を伴うことの多い先 天鎖耳の手術では，皮膚切開は大変重要なもの である。

一般的には, Saunders と Paparella) などの ように, 奇形耳介に対して耳後切開を用いるも のが多いが，私どもは，術側に小耳症が合併す る場合は，耳介形成術第 1 段階手術としての耳 垂の switch back と耳枠の皮下挿入を，外耳道 形成術, 聴力改善手術と同時に行うことが多い
（図 3 ）。従って，そのための皮膚切開は，形成 耳介に対しては耳内切開といえる。森満ら5), 瀧本 ${ }^{6)}$ ，船坂 ${ }^{2)}$ も耳年形成第 1 段階手術之の 同時手術を行っており，今後の敭勢上して形成 外科的手技がより積極的に導入されよう。

形成外科的観点からは，外耳道形成之耳年形 成，更には聴力改善手術が同時に同じ切開創で 行わ机ることが，局所の冹痕化やそれに上る循 環障害を考学るとより望ましいが，それには症 例ごとの複雑な奇形病態からして, 自ら限界が

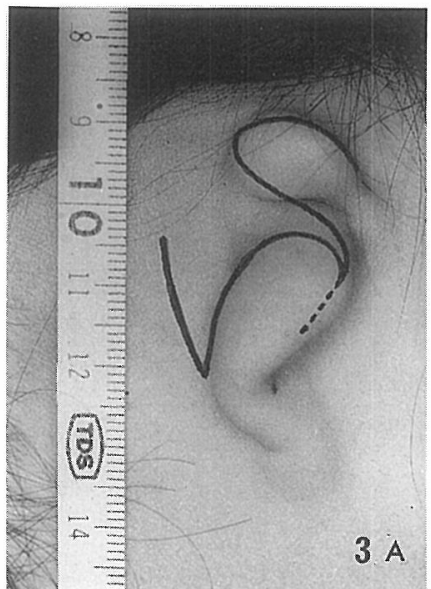

図 $3 \mathrm{~A}$ 皮䖉切開線

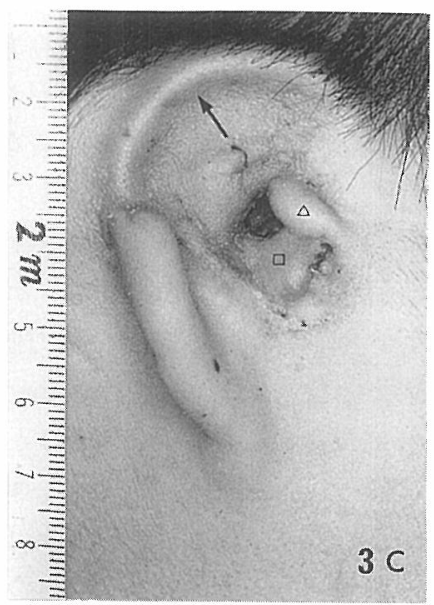

図 3 C 術後 3 週間目の局所所見

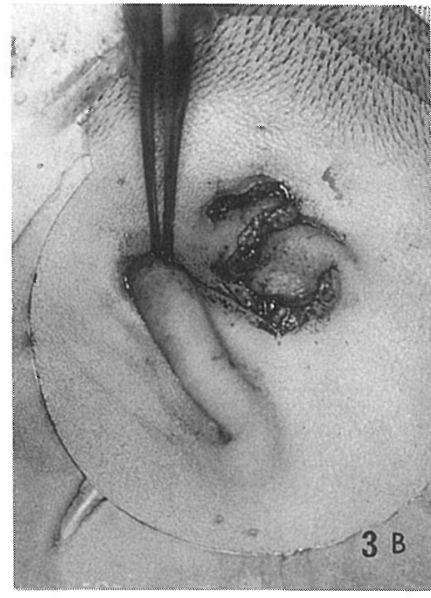

図 3 B 皮弁移動の検討(術中)
矢印：皮下に扱入されたシリコン枠による 耳輪部

$\triangle$ 印：残存軟骨を利用した形成耳珠

$\square$ 印：残存軟骨を床とした外耳孔部

図 3 先天鎖耳(小耳症合併)での耳形成と外耳道形成の同時進行例(右耳) 
あり，いまだ未解決の問題が多い.

2 ) 形成外耳道の再狭窄について

形成外耳道の再狭窄は，本症手術で最も重要 な術後合併症ともいえる，そのために，改善さ れた聴力が元に戻ってしまらだけでなく, 前述 したよらに，せっかく形成された外耳道の表皮 を深部に閉じこめるため，2 次的に真珠腫を発 症さすという不快な合併症もある.

先天鎖耳の術後狭窄で再手術 (拡大術) 要し た例を，小倉 ${ }^{7)}$ は $17.5 \%$ といい，全例術後 2 力 月以内に行い入口部軟部組織の切除と大腿分層 遊離皮弁で再植皮した． one tunnel 法を行った 船坂らは， 9 耳中 7 耳に再拡大術を行っている. 私ども8) も，かつて one tunnel 法で半数例に術 後 6 力月以内に再拡大術を行った.

外耳道再狭窄への予防対策としては, 初回手 術時に外耳孔，外耳道の内径を大きく作ること で, 瀧本 6) の正常より $3 \sim 5 \mathrm{~mm}$ 大, 村岡ら ${ }^{9)}$ の 2 倍大，私ども ${ }^{3)}$ の 1.5 倍大などの報告があ る。また，狭窄は外耳孔を中心に起こることか ら, 手術時この部の補強処理も重要で, 鈴木 ら 10) の骨膜, 筋膜, 皮膚の有茎弁の使用, 関 谷11) のL字型自家肋軟骨フレーム法, 高橋ら ${ }^{12)}$ の円筒型自家肋軟骨フレーム法など, 参考にす べき諸家の考按がある。いずれにせよ, 局所で の肉芽増生を押し返す強い支持組織が必要で, 他側耳介, 残存耳介, 残存軟骨など自家軟骨の 外耳道壁としての利用は, 症例に応じて常に考 慮されるべきである。

今回の対象症例での再狭窄は, 外耳道形成術 例で 18 耳中 4 耳, 鼓室形成術例で19耳中 1 耳で あった. 前者の 4 耳中初回手術後 2 週間で外耳 道拡大術と再植皮を行った 1 耳は 5 歳の男児で, 脳硬膜の露出や脳脊髄液の漏出をみた, 鼓室へ の指南が得られなかった例であり, 他の 3 耳は それぞれ術後 2 年, 4 力月, 2 年で拡大術と再 植皮を行った中学生の男 2 例, 女 1 例であった. また, 鼓室形成術例の再狭窄例は 8 歳の片側性 先天性鎖耳の男児で, 術後 3 力月で外耳孔部分 の軟部拡大術と再植皮を行っている. 他のほと
んどの例で，外耳孔部分が術直後に比べて狭小 化傾向をみとめたのは, 前述した予防的処置と しての 1.5 倍大の外耳孔作製の妥当性を物語る ものと思われた。 李た，外耳道形成術例での 5 歳男児の再手術例は, 術後 2 週間目の拡大術に も示されるよらに，幼小な者汪どこの部の肉芽 増生傾向が強いことを示唆している3)。

3 ) 聴力改善と改善聴力の維持について

本シリーズに扮ける18耳の外耳道形成術例中 5 耳, $27.8 \%$ で臨床上有意な聴力改善が得られ たことは，かつて私ども7)が集計，報告したよ ら飞, 昭和 30 年 1 月から 53 年 12 月までの自験例 での $13.3 \%$ に比べても 2 倍の高率であり，これ は one tunnel 法による効率のよい伝音効果, あるいは極小鼓室に打いても十分形成外耳道之 の連絡をつけることによる結果かと考兄られる. 一方, 同じ集計報告にある, 当時の伝音系奇形 例全体を通じての鼓室形成術例の聴力改善率 30 $\%$ も, 先天鎖耳のみを扱った本稿での $84.2 \%$ と いら高い数字と対比させる時, そこにCTなど 画像診断学の進歩や，手術手技，材料のそれも 含めた多角的な医療水準の上昇が一因として考 えられる13).

初回手術で鼓室形成術を行った全例を概観す る表 4 から明らかなように，正型およびその変

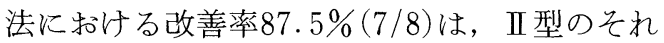
80\%(8/10) に比べて少なからず高率である.こ れは, この種の奇形例で多い奇形ッチ骨の周囲 骨壁への瘉合例など術後に再固着を起こしやす い奇形ツチ骨・キヌタ骨を除去し，奇形性でも 可動なアブミ骨を確認して処理すれば， III型に 扣いても，特にその変法に执いては聴力改善の 可能性が大きく, かつ術後の聴力低下も少ない ことを示している.この点 Schuknecht ${ }^{14)}$ の 0.5, $1,2,4 \mathrm{kHz}$ の平均聴力で $30 \mathrm{~dB}$ かそれ以内の もの $50 \%$ という成績は，きびしい判定基準から みて，良好なものとい光る。 De La Cruz ら ${ }^{15)}$ は, 骨導值下 $30 \mathrm{~dB}$ かそれ以内のもの $73 \%$ と 報告している.

一方, 聴力低下が原因で行った再手術は, II 
型症例で 10 耳中 3 耳 $(30 \%)$ ， III型症例で 8 耳中 2 耳 (25\%)であった。初回手術後再手術を行う までの期間は 5 耳中 4 耳で 1 年, 残り 1 耳で 2 年であり，聴力低下の原因が，前 4 耳では耳小 骨連鎖と形成鼓膜との離開，残り 1 耳ではキヌ タ・アブミ関節の離断であった。 De La Cruz ら ${ }^{15)}$ も, 改善聴力の低下の要因は, 鼓膜の lateralization によるとし，56耳中 14 耳 $(25 \%)$ にそれを経験している。

\section{まとめ}

先天鎖耳の臨床で問題となる重要なものに次 の諸点がある。

まず，中耳腔に直結した外耳道を作ること， そして奇形中耳で聴力改善を得ること, 形成さ れた外耳道を維持し, かつ改善聴力を永続させ ることである。

本稿では, 最近 8 年間に私どもが経験した先 天鎖耳手術例計34例37耳について, 臨床的重要 点を中心に検討し, 次のように結論した。

1. 先天鎖耳での外耳道形成に执いて，術後 の外耳道再狭窄を予防するためとは，形成外耳 道の外耳孔を中心に，正常の1.5倍以上の径を 作る.

2. 形成外耳道が中耳腔に到達した場合, 初 回手術としての鼓室形成術の聴力改善は, 奇形 性であってもアブミ骨の運動性が良好なら，十 分満足すべきものとなる。

3. 外耳道が保たれている場合, 術後の改善 聴力の低下には，原因として形成鼓膜と奇形耳 小骨連鎖との離開を考える。

擱筆するにあたり，本稿に使用した data の整理に ご協力いただいた中井貴世子, 小坂道也, 鶴迫裕一, 中島智子，福島邦博の諸君に深謝いたします。

\section{文献}

1) Meurman $Y$ : Congenital microtia and meatal atresia. Arch Otolaryngol $66:$ 443 463, 1957.

2）船坂宗太郎，馬場道忠，滋賀秀壮：One tunnel approach による鎖耳鼓室形成術.臨床耳科 1： 34 35, 1974.

3）増田 游: 外耳道閉鎖症の形成. JOHNS 6 : 413〜418, 1990.

4) Saunders WH and Paparella MM : Atlas of Ear Surgery. CV Mosby company, Saint Louis, 1968.

5）森満 保, 松元一郎, 高橋政見, 他: 先天性外 耳道閉鎖症の手術. 第81回日本耳鼻咽喉科学会 総会予稿集 : $100,1980$.

6）瀧本 勲：先天性外耳道閉鎖症の治療. 臨床耳 鼻咽喉科頭頸部腫瘍外科全書 $2 \mathrm{~A}$ 耳臨床 1 (大 内 仁, 中野雄一編). 133 149頁, 金原出版, 東京, 1986 .

7）小倉義郎：伝音系奇形. 第80回日本耳鼻咽喉科 学会総会宿題報告モノグラフ, 1979.

8）増田 游, 小倉義郎, 西岡慶子, 他 : 小耳症 · 外耳道閉鎖症合併例の手術療法. 日形会誌 5 ： 796 797, 1985.

9）村岡道徳, 中井義明, 八木英晴, 他：外傷性外 耳道閉鎖症の 2 例. 耳喉 $59: 373 \sim 378,1985$.

10）鈴木淳一，児玉 章：自家軟骨対側耳介軟骨 · 骨の移植による耳介・外耳道・鼓室形成. 臨床 耳科 $7: 24 \sim 25,1980$.

11）関谷 透：先天性外耳道閉鎖症 - one stage reconstruction technique - . 耳喉 $49: 27 \sim 31$, 1977.

12）高橋 良, 飯田 収：外耳道閉鎖に対する新形 成手術法について.形成外科 $6: 167 \sim 172,1963$.

13）増田 游：先天性伝音性難聴の手術. 日本医事 新報 $3367: 127,1988$.

14) Schuknecht HF : Congenital aural atresia. Laryngoscope 99 : 908 917, 1989.

15) De La Cruz A, Linthicum Jr FH and Luxford WM : Congenital atresia of the external auditory canal. Laryngoscope 95: 421 427, 1985.

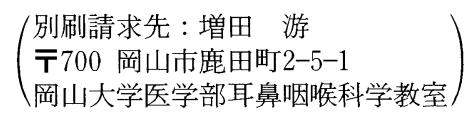

